\title{
МИКРОСТРУКТУРА, ВЕЩЕСТВЕННЫЙ СОСТАВ КИАНИТОВЫХ ПОРОД ХИЗОВААРСКОГО МЕСТОРОЖДЕНИЯ И ПУТИ ИХ ПРИМЕНЕНИЯ
}

\author{
Завёрткин А.С., Гоголев М.А., Фролов П.В.
}

Институт геологии КарНЦ РАН, Петрозаводск, таg-333@таil.ru

Кианитовые концентраты, наряду с дистен-силлиманитовыми, могут найти применение при производстве огнеупорных порошков для футеровки индукционных тигельных печей, выплавляющих чугун и цветные сплавы. Работы по улучшению стойкости футеровки индукционных тигельных печей для цветных сплавов, наряду с улучшением технологии, ведутся в направлении выявления новых составов огнеупорных масс, более стойких в службе. При этом внимание уделяется получению плотного черепка тигля, считается, что чем плотнее футеровка, тем она долговечнее в эксплуатации. Основная роль здесь отводится правильно подобранному зерновому составу и способу набивки тигля или подового камня, если речь идет о канальной индукционной печи. Правильно подобранный зерновой состав кварцитовых или высокоглиноземистых масс обеспечивает отсутствие трещин в футеровке в периоде службы. Из практического опыта эксплуатации индукционных тигельных печей промышленной и высокой частоты емкостью 1т, выплавляющих кремнистую латунь и алюминиево-железистую бронзу, известно, что стойкость кислой футеровки этих печей находится в пределах сотни плавок. Предварительный обжиг кварцитовой массы перед футеровкой печей не увеличил ее стойкость. Некоторое увеличение продолжительности службы тигля из кварцитовой футеровки вызывает введение в ее состав 10-12\% электрокорунда.

Футеровку на основе глиноземистых материалов (дистен-силлиманитовая футеровочная масса с борной кислотой) в индукционных печах начали применять сравнительно недавно. Обычно такая футеровка выполняется из пластической массы и требует медленной сушки. Обладая высокой огнеупорностью (до $1800^{\circ} \mathrm{C}$ ), футеровка на основе глинозема, так же, как кварцитовая, не обеспечивает объемной стабильности, а стоимость ее дороже кварцитовой. Поэтому, при плавке чугуна, глиноземистая футеровка, как набивная, так и из фасонных штучных изделий, широко применяется там, где необходима длительная стойкость ее - в канальных индукционных, крупных тигельных печах.

Раскисление металла, легирование, десульфурация, вакуумная обработка сплава существенно снижают стойкость огнеупорной футеровки. В связи с этим, все большее применение находят высокоглиноземистые огнеупоры, в том числе из обогащенного природного сырья силлиманитовой группы, благодаря высоким показателям термической стойкости, механической прочности, способности противостоять в процессе службы разрушающему действию расплавов металла и шлака при высокой температуре.

Из опыта эксплуатации кианитовой футеровки в индукционных печах следует сделать вывод о том, что при обжиге тигля до $1450^{\circ} \mathrm{C}$ (плавка чугуна и цветных, на основе меди, сплавов) происходит разрыхление структуры кианита вследствие полного превращения в муллит. При более высоких температурах, во время термовременной обработки синтетического чугуна в процессе проведения плавки $\left(1500-1550^{\circ} \mathrm{C}\right)$ протекает процесс спекания.

Для силлиманита, входящего в состав дистен-силлиманитовой футеровки тигля, характерными являются непрерывные процессы спекания и муллитообразования, достигающие одновременно почти полного завершения при плавке легированной стали $1650-1750^{\circ} \mathrm{C}$.

Одним из промышленно значимых высокоглиноземистых месторождений России является Хизоваарское месторождение кианитовых руд, которое расположено в Лоухском районе Северной Карелии и является наиболее перспективным объектом глиноземистого сырья, суммарные запасы которого составляют 25.5 млн. т по категориям $\mathrm{B}+\mathrm{C}_{1}+\mathrm{C}_{2}[1]$.

В процессе работ изучался минеральный и химический составы проб, физико-химические, флотационные свойства минералов, анализировались возможные варианты технологических схем обогащения, методы обогащения и типы флотационных реагентов.

На Хизоваарском месторождении геолого-минералогические сорта представлены светлосерыми рудами с игольчатым кианитом и разделяются на два типа, отличающихся содержанием кремнезема и глинозема, а также входящего в их состав кианита. Первый тип руд представлен сле- 

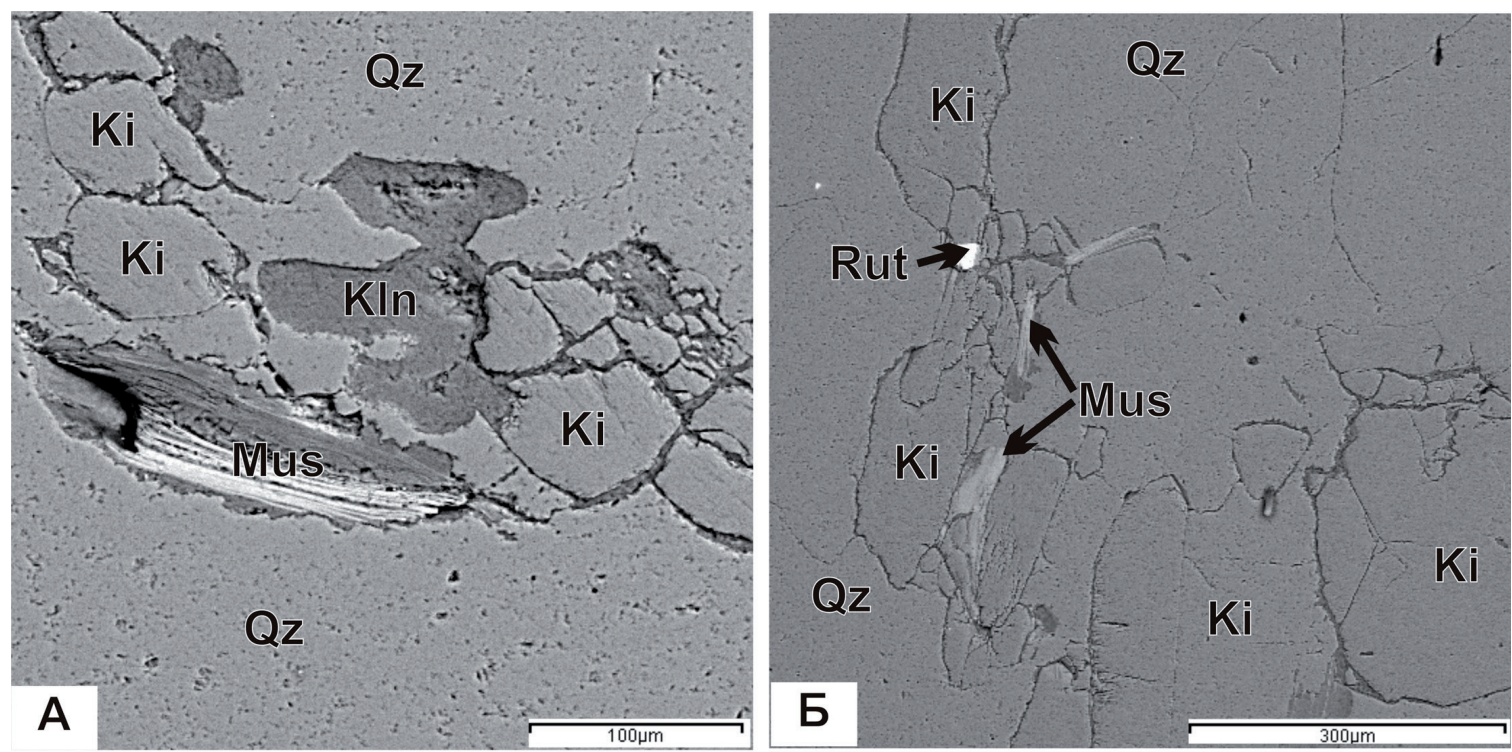

Рис. 1. Кианитовые руды Хизоваарского месторождения.

A - первый и Б - второй тип руд (фото в отраженных электронах). Ki - кианит, Kln - каолинит, Mus - мyсковит, Qz - кварц, Rut - рутил.

дующим минеральным составом: кварц 70-85\%, кианит 10-25\% (главные); мусковит, плагиоклаз, биотит, графит, тальк (второстепенные); пирит 0-10\%, пирротин, магнетит (рудные); рутил, апатит, сфен, гранат (акцессорные) (рис. 1 А). По данным сканирующей электронной микроскопии, содержание в кианите глинозема составляет 60-62 мас. \%.

Второй тип содержит: кварца 50-60\%, кианита 10-40\% (главные); мусковит, графит (второстепенные); пирита 0-10\%, пирротин, арсенопирит, рутил (рудные) (рис. 1 Б). Содержание глинозема в кианите варьирует в интервале от 57 до 63 вес. \%.

Исследование микротвердости и коэффициентов анизотропии различных морфологических форм кианита позволяет выделить их как типоморфные характеристики различных генетических типов руд [2], что теоретически будет оказывать влияние на энергозатраты в процессе подготовки материала. Институтом геологии КарНЦ РАН выполнен комплекс лабораторных технологических исследований применения при промышленном выпуске кианитового концентрата реагентов местного производства, талового масла, выпускаемого Сегежским ЦБК [3]. Руды обогащали до содержания глинозёма в концентрате от 41 до 60 \%, при этом концентрат содержал незначительное количество оксидов железа и щелочей. Полученный концентрат удовлетворяет требованиям отечественной промышленности огнеупоров.

В настоящее время на Хизоваарское месторождение кианитовых руд нет действующей лицензии. На участке существует опытный карьер, по изученности объект является перспективным для вовлечения в промышленную эксплуатацию, а, благодаря выгодному расположению, месторождение может быть освоено для получения кианитового концентрата.

Трудности, вызванные сложностью обогащения кианитовых руд с целью получения кианитового концентрата, остаются до настоящего времени одной из основных причин незначительного применения этого вида глинозёмистого сырья в огнеупорных и формовочных материалах.

\section{Литература}

1. Борисов П.А., Волотовская Н.А. Хизоваарское месторождение кианита (КФССР) // Советская геология. 1941. № 6. С. 82-86.

2. Гаранжа А.В. Особенности микротвёрдости кианита в зависимости от генетического типа руд Хизоваарского месторождения (Северная Карелия) // Геолого-технологическая оценка индустриальных минералов и пород Республики Карелия и отдельных регионов Европейского континента. Петрозаводск. 1997. С. 51-54.

3. Каменева Е.Е., Скамницкая Л.С. Обогащение минерального сырья Карелии. Петрозаводск, 2003. 228 с. 